\title{
ФОЛЬКЛОРИСТИЧНА ДІЯЛЬНІСТЬ ПАНТЕЛЕЙМОНА КУЛІША: ПОЛЬСЬКИЙ КОНТЕКСТ
}

\author{
Василь Івашків \\ Львівський національний університет імені Івана Франка \\ ORCID: 0000-0002-9335-0338
}

\begin{abstract}
Анотація. Стаття окреслює польський контекст фольклористичної діяльности Пантелеймона Куліша 1840-1850-х років, який склали співпраця українського фольклориста й письменника 3 польськими митцями та культурними діячами, зокрема Міхалом Грабовським, а також Константієм Свідзінським, Едвардом Руліковським, котрі тоді жили в Україні. Результатом були публікація перекладів численних текстів легенд і переказів із рукописного збірника Куліша та аналіз особливостей праці Куліша-фольклориста у великій статті Грабовського $O$ gminnych ukraińskich podaniach у журналі «Rubon» (1845). Підкреслено роль Грабовського у формуванні змісту та концепції унікальної праці Куліша Записки о Южной Руси (1856, т. 1; 1857, т. 2), що не має аналогів у тогочасній фольклористиці та етнології.
\end{abstract}

Ключові слова: український фольклор, польсько-українська співпраця, Пантелеймон Куліш, Міхал Грабовський

Польський контекст фольклористичної діяльности - це одна із сторінок різнобічної творчої співпраці Пантелеймона Куліша з багатьма визначними польськими культурними та громадськими діячами, що тривала упродовж значного часу. Для прикладу назву поета Тадеуша Ладу-Заблоцького (співпрацював із Кулішем у справі перекладу українських народних дум французькою мовою), Вацлава Мацейовського (знайомство з цим відомим польським істориком права і культури датують березнем 1847 р., коли Куліш перебував у Варшаві), професора хімії Університету святого Володимира Стефана Зеновича (Куліш зблизився 3 ним у Луцьку 1841 р.), Ромуальда Подберезького-Друцького (переклав ранні романтичні оповідання Куліша). Відзначу також знайомство Куліша $з$ братами Германом та Ігнацієм Головінськими (з ними Куліш познайомився у середині 1840-х років за сприяння Міхала Грабовського); спеціяльної уваги заслуговує творча співпраця українського романтика 3 молодшим із братів Ігнацієм, котрий, як відомо, був визначним церковним діячем, єпископом, професором богослов'я, а також літератором. 
Куліш переклав його «чарівно-зворушливе» (вислів Пєтра Плєтньова) оповідання Życie mojej matki, що було опубліковано з передмовою Куліша у 10-му номері журналу «Современник» за 1846 рік.

1844 роком датовано переклад-переробку уривка 3 четвертої частини романтичної епопеї Адама Міцкевича Дзяди під заголовком Любовь за гробом, виконаного, за словами самого автора, під впливом власних любовних переживань. За твердженням Євгена Нахліка, вибір саме такого тексту пов'язаний із тим, що драматичні залицяння Куліша до Олександри Білозерської (згодом дружина Куліша) були «подібні до страждань міцкевичівського Густава» ${ }^{1}$. Герой уривка Густав наділений рисами популярного у романтиків вічного жида, який не знає спокою.

Звісно, були й інші знайомства, а інтерес до польської історії, літератури й культури Куліш зберігав практично все своє життя: він спілкувався з Осипом Сенковським (бароном Брамбеусом), Юзефом-Ігнацієм Крашевським; добре знав творчість Северина Гощинського, Антонія Мальчевського, Тимка Падури та інших польських романтиків.

Чимало контактів було в Куліша з польськими суспільно-культурними і політичними діячами і в час його перебування у Львові на початку 1880 -х років, коли він зокрема опублікував цікаву публіцистичну брошуру Крашанка русинам і полякам на Великдень 1882 року, вийшов з російського громадянства тощо. Зазначу, що Кулішева Крашанка, яка мала присвяту: «Се христосуванне 3 друзями й ворогами бідолашний автор, стоячи між Сциллою і Харибдою, благоговійно присвячує слободженим од нашої великої туги мученикам чоловіколюбства ТАРАСУ ШЕВЧЕНКОВІ і АДАМУ МІЦКЕВИЧОВІ», викликала неочікувано жорстку критичну реакцію кількох тогочасних українських письменників (назву хоча б Миколу Костомарова та Данила Мордовця). Пишучи про українську й польську нації як «дві гарні, найгарнійші в світі слов'янські народності»» та характеризуючи особливості їхніх взаємовідносин в історичній ретроспективі, Куліш у післямові до другого видання брошури висловив подяку польській інтелігенції («дякую польській інтелігенції, дякую братерським серцем за ії просвічене вітанне мого поклику до згоди з русинами»³), а також окреслив перспективу майбутнього українського й польського народів, зазначивши, що «позад нас - тьма завзятого недомислу; перед нами - світ миролюбивої науки» ${ }^{4}$.

Заявлену тут тему значною мірою обгрунтував сам Куліш в автобіографії Жизнь Куліша, праці Хуторская философия и удалённая от света

Є. Нахлік, Пантелеймон Куліш: Особистість, письменник, мислитель [Наукова монографія у 2-х томах], Київ 2007, т. 2: Світогляд і творчість Пантелеймона Куліша, с. 261.

2 П. Куліш, Крашанка русинам і полякам на Великдень 1882 року, Львів 1882, с. 20.

Там само, с. 33.

4 Там само, с. 33. 
поэзия, мемуарах Около полустолетия назад. Литературные воспоминания та інших працях. Так, у мемуарах Около полустолетия назад, які він написав 3 приводу «библиографического известия о [...] “невышедшей книге", напечатанной в 1847 году в Москве под заглавием Украинские народные предания» ${ }^{5}$, загалом ішлося про Кулішеве життя у 1840ві роки. Нагадаю, збірник української фольклорної прози Украинские народные предания справді було підготовлено і віддруковано в Москві 1847 року (видавцем був Осип Бодянський), але через політичні причини (розгром Кирило-Методіївського братства та арешт Куліша) книга побачила світ лише 1893 року.

У названих мемуарах Куліш одразу повів мову «о так называемом украинском отделе польской литературы» ${ }^{6}$, акцентуючи на тому, що любов до українського колориту в «поляков доходила нередко до превращения обстановки и быта в подобие козакоукраинщины» ${ }^{7}$. Одним із найбільш яскравих прикладів у цьому плані для Куліша був великий Міцкевич, котрий, за словами українського романтика, «не раз настраивал свою лиру на украинский лад» ${ }^{8}$, а в «своей бессмертной поэме Pan Tadeusz, этой славянской “Одиссеи”, вздыхал по Киевщине»9.

Оповідаючи про зацікавлення польською культурою у свої молоді роки, Куліш згадав проживання в родині бідного шляхтича в Києві десь на межі 1830-1840-х років у час навчання в місцевому університеті - саме тут, за його словами, він уперше почув польську мову, а його першою польськомовною книжкою була хрестоматія чи поетична антологія, з якої український романтик вивчив напам'ять прекрасну баладу Міцкевича Świtezianka, навіть вважаючи іiі за рисами поетичного ладу цілком українською. 3 цього ж часу він і полюбив польську мову, що стало причиною того, що його київські знайомі навіть вважали Куліша ополяченим, хоча, за своїм зізнанням, він був тоді яскравим прибічником козаччини в «костомаро-шевченковском смысле слова» ${ }^{10}$.

1840-ві роки були другим етапом Кулішевого сприймання національного фольклору, який настав після пізнавально-творчого періоду (по-іншому, етапу інтуїтивного осягнення краси, поетичності, а згодом і глибинного змісту народної пісні, якими були дитячі роки та період навчання в Новгород-Сіверській гімназії). Я уже писав, що тут ми можемо вести мову про дві фази Кулішевого інтересу до народної словесності:

П. Куліш, Около полустолетия назад. Литературные воспоминания, [в:] Пантелеймон Куліш. Матеріали і дослідження, Львів-Нью-Йорк 2000, с. 110.

6 Там само, с. 113.

7 Там само.

8 Там само.

9 Там само.

10 Там само, с. 115. 
письменницьку (межа 1830-1840-х років) та фіксаиійно-дослідницьку (1843-1847-мі роки) ${ }^{11}$.

1843 року Куліш став членом-співробітником щойно утвореної Київської археографічної комісії (нагадаю, іiї формальним головою був Ніколай Пісарєв - саме про нього йдеться у відомій сатиричній поемі Тараса Шевченка Юродивий), але фактично керував нею барон Станіслав Шодуap. Відтак, за завданням Комісії Куліш влітку того ж року вирушив в експедицію тодішньою Київщиною, маючи із собою відповідні документи на право вилучати 3 архівів тамтешніх монастирів та магістратів давні акти. За своїми зізнаннями, молодий український письменник (тоді йому було лише 24 роки) об'їхав і обійшов пішки територію, на якій більше сімдесяти років тому діяли гайдамаки.

Куліш був прекрасно обізнаним із тогочасними літературними творами, причому й тими, що публікувалися іншими мовами. Увагу молодого письменника привернула творчість польського романтика Міхала Ірабовського (1804-1863), котрий жив у містечку Олександрівка біля Чигирина, а у своєму романі Stanica Hulajpolska досить докладно описав ці гайдамацькі місця. У цитованих вище мемуарах Куліш зазначав:

«Особенно занял меня [...] роман Михаила Грабовского Stanica Hulajpolska. В то время он показался мне почти вальтерскоттовским. Я узнал, что Грабовский живёт близ Чигирина, в наследственном местечке Александровке, и стал мечтать о том, как бы его увидеть» ${ }^{12}$.

На той час Грабовський був уже досить відомим літературним критиком та белетристом, зокрема своїми статтями про українську школу в польській літературі та український фольклор, а також як автор кількох повістей з української тематики (передусім про гайдамаччину).

Увага Грабовського до української тематики була не випадковою. Олена Юровська, покликаючись на свідчення С. Гощинського, писа-

\footnotetext{
11 В. Івашків, Фольклор у науковому та письменницькому дискурсі Пантелеймона Куліша (1840-1850-mi роки), «Бюлетень Наукового Товариства ім. Шевченка в Америці» 2019, число 48 (64), с. 11.

12 П. Куліш, Около полустолетия назад. Литературные воспоминания, [в:] Пантелеймон Куліш. Матеріали і дослідження, Львів-Нью-Йорк 2000, с. 118. Думка Куліша була цілком слушною. Український дослідник В. Я. Гнатюк писав, що відповідаючи Олександру Тишинському, «Грабовський погоджується, що хисту повістярського він справді не має, але в нього $€$ певна метода, метода історичного роману, що він засвоїв од найкращого романіста Вальтер Скотта. Грабовський не бачить у польській літературі гідного представника цього роду літератури» (В. Гнатюк, Польський літератор М. А. Грабовський і його приятелювання з П. О. Кулішем, «Записки історично-філологічного Відділу Всеукраїнської Академії наук» 1929, кн. XXIII, с. 101).
} 
ла, що в дитинстві він чув українську мову та пісню, а в час навчання в Уманській гімназії це використовував:

«Грабовського товариство дуже любило й цінило. Він знав чимало пісень українських, любив вірші слухати й читати» ${ }^{13}$.

Висвітлюючи тему перекладів українських народних пісень польською мовою, відомий фольклорист та літературознавець Роман Кирчів відзначив працю Ірабовського O pieśniach ukraińskich, котра містила й численні народнопоетичні українські твори (у додатку до статті було вміщено тексти чотирьох українських народних дум) у його перекладі. За висновком ученого, всі вони

«відзначаються адекватністю передачі змісту пісень і дум з усіма характерними їм особливостями пісенної оповіді, послідовністю розгортання і чергування картин, з властивими оригіналам народними ідейними акцентами, оцінками й характеристиками історичних подій та явищ» ${ }^{14}$.

Український дослідник ствердив, що Грабовський продемонстрував «тонку чутливість щодо передачі ритмомелодики дум, їх вільного римування, зокрема властивої їм дієслівності рим і навіть епіфор» ${ }^{15}$.

Варто додати, що польський перекладач Леонард Совінський (18311887) у тижневику «Kłosy» (1875, № 509, s. 195-198) опублікував переклад української народної думи про Марусю Богуславку, «виконаний на основі українського тексту із Записок о Южной Руси Куліша» ${ }^{16}$, а сам Куліш у передмові до цього перекладу названий як «najznakomitszy znawca ukraińskiej literatury ludowej» ${ }^{17}$.

Як бачимо, письменницькі зацікавлення Грабовського були суголосними Кулішевим задумам принаймні у трьох аспектах - захоплення творчістю Волтера Скотта, висвітленням теми Коліївщини 1768 року та вдумливе розуміння специфіки та самобутності українського фольклору: український романтик планував удосконалювати свою письменницьку майстерність та записувати й публікувати народнопоетичні твори, зокрема на теми недавнього минулого.

\footnotetext{
13 О. Юровська, Куліш і Грабовський, «Україна» 1929, книга 36, с. 73.

14 Р. Кирчів, Переклади украӥнських пісень польською мовою, [в:] той самий , Студї з українсько-польського етнокультурного пограниччя, Львів 2013, с. 250.

15 Там само, с. 251.

16 Там само, с. 271.

17 L. Sow[iński], Duma o Marysi Bogusławiance (z małoruskiego), «Kłosy» 1875, 20.03. (01.04), № 509, s. 195.
} 
Українська літературознавиця О. Юровська акцентувала на різнобічності впливу Грабовського на Куліша:

«М. Грабовський, яко письменник-романіст, естет, історик, ідеолог певної літературно-громадської течії, яко проста й щира людина, з якою був Куліш добре знайомий, міг мати справді вплив на мислення Кулішеве» ${ }^{18}$.

Молодому Кулішеві були близькими й літературно-естетичні погляди Грабовського, котрий, за висновком О. Юровської, вважав конче потрібним створити самобутню літературу, а для цього треба не вигадувати сюжети та форми, а брати їх з народної творчості. Для підтвердження своєї думки дослідниця подала таку цитату Грабовського:

«Щоб бути міцною, література мусить виходити з коріння народньої поезії, в ній відбивається найбільше життя народу» ${ }^{19}$.

Сам Куліш такі ідеї не лише не заперечував, а завжди підкреслював значущість впливу Грабовського та його літературної діяльности на свою творчість 1840 - початку 1860 -х років, що можна підтвердити цитатою з праці Хуторская философия и удаленная от света поэзия (1879): сам він

«высосал из книг польского украинца лучшее, что в них было, именно то, чего там не было написано, но возле чего автор ходил весьма близко и дал моему юношескому чутью, по запаху своей одежды, догадаться, в каких далеких, недоступных для меня местах он прогуливался» ${ }^{20}$.

Куліш зазначив, що свій останній твір повість Zamieć w stepach (1862), яку український романтик вважав найкращою, Грабовський присвятив саме йому. Як бачимо, Куліш вважав важливим не лише вплив творів Грабовського, а й його суспільно-політичних та літературних переконань.

Влітку 1843 р. Куліш потрапив до містечка Олександрівки, що біля Чигирина (тепер це Кропивницької області), попередньо пославши Грабовському свій перший історичний роман Михайло Чарнышенко, или Малороссия восемьдесят лет назад, який щойно вийшов із друку.

\footnotetext{
18 О. Юровська, Куліш і Грабовський, «Україна» 1929, книга 36, с. 72.

19 Там само, с. 76.

20 П. Кулиш, Хуторская философия и удаленная от света поэзия, Санкт-Петербург 1879 , c. 81.
} 
Про своє знайомство з Грабовським, якого називав «умною, светлою головою», Куліш сповістив листом з Олександрівки від 31 липня 1843 року Михайла Юзефовича:

«здесь познакомился я с известным М. Грабовским и нашёл в нём человека весьма умного и чрезвычайно трудолюбивого. Он пригласил меня провесть у него в деревне несколько дней и предоставил в моё распоряжение свою библиотеку и все свои бумаги, которых у него множество»²1.

Олесь Федорук зазначив, що того ж дня, 31 липня 1843 р., про свою зустріч із Кулішем Грабовський написав великого листа Ю. І. Крашевському 22.

Для українського письменника й фольклориста таке знайомство було дуже важливим, адже саме «завдяки Грабовському Куліш відкрив для себе польські джерела з історії України, зав'язав взаємини з польськими культурними діячами (передовсім із Константієм Свідзінським). Це сприяло розширенню його кругозору, про що він завжди згадував із вдячністю» ${ }^{23}$. Стосунки Куліша й Грабовського мали характер творчої співпраці, адже, як писав сам Куліш,

«я Грабовскому сообщил много такого, что его удивило, но зато у него нашёл такие материалы для истории Малороссии, о которых нам, заднепрянам, и не снилось» ${ }^{24}$.

За зізнанням українського письменника, роман Михайло Чарнышенко Грабовському не сподобався, але польський критик натомість високо оцінив укладену з народних дум та Кулішевих стилізацій поему-епопею

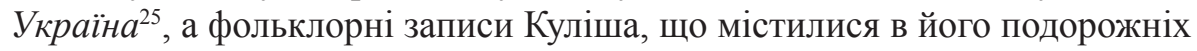
альбомах, взагалі вважав унікальними. У мемуарах Около полустолетия назад. Мои литературные воспоминания, згадуючи про це, Куліш писав:

«Мои альбомы, содержавшие в себе и записанные мною предания, и портреты самих рассказчиков [Примітка П. Куліша: <Один из них я подарил

21 Пантелеймон Куліш - Михайлу Юзефовичеві. Лист від 31 липня 1843 року, [в:] П. Куліш, Повне зібрання творів. Листи, Київ 2005, т. 1: 1841-1850, упоряд., комент. О. Федорук, с. 19.

22 П. Куліш, Повне зібрання творів. Листи, Київ 2005, т. 1: 1841-1850, упоряд., комент. О. Федорук, с. 355-358.

23 Там само, с. 366-367.

24 Пантелеймон Куліш-Михайлу Юзефовичеві..., с. 20.

25 Вище йшлося про прекрасно виконані переклади українських народних дум, котрі Грабовський помістив у додатку до своєї статті O pieśniach ukraińskich. 
В.В. Тарновскому ${ }^{26}$. [...] $>$ ] привели его [Грабовського. - В. І.] в восхищение, так что часто, сидя за столом в кругу своего семейства, он вдруг повторял из них отрывок, точно на сцене; например, следующий: “Здорові, сучаки! - Здорові, пане! - А що ви? Не орете? - Нi, пане. - А ми ж оце почали орати"» ${ }^{27}$.

Захоплений змістом і красою українського народного поетичного слова, у віленському журналі «Rubon» (1845, t. 6, s. 145-216), який видавав Казимір Буйницький, Грабовський вперше опублікував Кулішеві фольклорні записи (про це певний час не знав і сам Куліш). Володимир Якович Гнатюк навів цитату Грабовського про те, що Куліш «oryginalny swój rękopism mnie zostawił», а Куліш дізнався про цю публікацію лише згодом, але «никогда не имел времени посмотреть, как [он] это сделал» ${ }^{28}$.

Згодом, через два роки, Куліш увів ці тексти до збірника «Украинские народные предания», а 1856 року - до своєї унікальної народознавчої книги «Записки о Южной Руси». Як приклад фольклористичної співпраці Куліша й Грабовського назву публікацію на початку першого тому «Записок о Южной Руси» народної легенди про лицаря Михайлика і Золоті ворота: там є Кулішева примітка про те, що і Грабовський записав цю ж легенду в селі Гвоздів біля Києва - це підтверджує публікація у зазначеному вище журналі «Rubon» (c. 161-162). Отже, виходить, що український народнопоетичний твір спершу оприлюднив польський, а не український фольклорист.

Загалом співпраця Куліша-фольклориста і Грабовського, за свідченням українського романтика, виглядала так:

«Когда я возвращался из убогих хат, из куреней, пасек или левад в палац Грабовского, он жадно слушал мои рассказы и чтения. Я давал ему урок из украинской народности и тут же получал щедрую плату критикою. Всё выработанное польскою интеллигенциею, всё усвоенное ею от Европы путём культуры, делалось моим достоянием чрез посредство Михаила Грабовского ${ }^{29}$.

\footnotetext{
26 Йдеться про Альбом для рисованья и записывания (зберігається в Чернігівському обласному історичному музеї імені В.В. Тарновського - інвентарний № Ад. 225-34/1933. 34 аркуші). Це записна книжка 3 малюнками та нотатками, датована 1843-1856 роками. Деякі інші записні книжки зберігаються в рукописних фондах ІМФЕ ім. М. Рильського НАН України.

27 Тут цитується уривок з народного переказу Пребывание Максима Зализняка в Черка$c a x$, поміщений і в зазначеному вище альбомі, і Записках о Южной Руси (П. Куліш, Повне зібрання творів. Наукові праиі. Публіцистика, Київ 2015, т. 3, Записки о Южной Руси, у 2 кн., кн. 1, упоряд., підгот. текстів, стаття, комент. В. Івашків, с. 175).

28 В. Гнатюк, цит. праця, с. 108.

29 П. Кулиш, Хуторская философия..., с. 89-90.
} 
Куліш відзначав, що селяни в Олександрівці були з ним відверті і балакучі, бо їм не було що приховувати, а Грабовський «был так популярен в Александровке, как Вальтер Скотт в Абботофордте» ${ }^{30}$.

Як бачимо, завдяки значною мірою польському письменникові та критикові і з'явилася новаторська книга Куліша Записки о Южной Руси - це не був звичайний збірник фольклорних текстів, а концептуально продумана народознавча праця, адже польський та український романтики між собою дискутували на такі зокрема теми:

«Откуда в украинском простонародье явилось, как в нём образовалось это сознание собственного достоинства? Откуда в нём эта деликатность и утончённость взаимных отношений? В какой социальной среде, в какой момент истории, под какими влияниями выработал он в себе эти благородные черты характера? $»^{31}$.

Закономірно, що саме Записки о Южной Руси (1856, т. 1; 1857, т. 2) стали вінцем не лише фольклористичної, а й загалом народознавчої діяльности раннього Куліша. Унікальности видання сприяли підхід до фольклорних текстів як неповторних зразків народнопоетичної творчости і намагання якомога повніше та яскравіше відтворити колорит обстановки, в якій функціонувала українська народнопоетична творчість. За словами Ватрослава Ягіча, праця Куліша «справляє на читача враження, нібито він прийшов в етнографічний музей» ${ }^{32}$, а Алєксандр Пипін зазначив, що «Записки» «не були ні вченим трактатом, ні голим збірником творів народної поезії, а представили цілком нову форму етнографічного дослідження» ${ }^{33}$.

3 Записками о Южной Руси був добре обізнаний професор Львівського університету Адам Фішер, котрий у своєму нарисі Rusini. Zarys etnografji Rusi зокрема писав, що «lecz szczególnie ważna była książka P. Kulisza pt. Zapysky o Jużnoj Rusi (1856)» ${ }^{34}$. Український дослідник Р. Кирчів звернув увагу на те, що А. Фішер у розвідці Drzewa $w$ wierzeniach i obrzędach ludu polskiego (Lwów, 1939)

«мотив відквітаючої гілки розглядає в порівняльному плані українські фольклорні сюжети про оживлення увіткнутої в землю сухої палиці сльо-

\footnotetext{
30 Той самий, Около полустолетия назад..., с. 140.

31 Той самий, Хуторская философия..., с. 91.

32 И.В. Ягич, История славянской филологии, Санкт Петербург 1910, с. 496.

33 А. Пыпин, История русской этнографии, Санкт Петербург 1891, т. 3: Этнография малорусская, с. 194.

34 A. Fischer, Rusini. Zarys etnografji Rusi. Z tablicami i 33 ilustracjami, Lwów-WarszawaKraków 1928, s. 167.
} 
зами розкаяного грішника-розбійника з Записок о Южной Руси П. Куліша й народної легенди про каяття Мадея, яку в свій час творчо трансформував Іван Вагилевич у романтичній поемі Мадей (1837)» ${ }^{35}$.

Роль Грабовського відчутна і при публікації Рассказа современника поляка о походах против гайдамак (Записки о Южной Руси, т. 2) - його рукописний текст польською мовою Кулішеві 1843 р. надав саме Грабовський, котрий видрукував його спершу 1843, а потім і 1845 року ${ }^{36}$. Хоча Рассказ современника поляка значною мірою дисонував із змістом поміщених у першому томі фольклорних матеріялів, зокрема переказів про Коліївщину та загалом гайдамацький рух, він став основою для відомого Кулішевого оповідання «Січові гості (Споминка старого діда)» (Основа, 1862, Січень, с. 1-12), а ще раніше матеріялу збірника «Украинские народные предания» під назвою «Чуприна і Чортоус». Копія цього рукопису зберігається в архівних фондах ІМФЕ імені Максима Рильського НАН України.

Незважаючи на досить відчутну вікову різницю (Грабовський був на 15 років старшим від Куліша), їхня дружба і співпраця тривала упродовж усього життя польського романтика. Куліша захоплювала ерудиція його польського товариша:

«ума и поэзии в нём (себто Грабовському. - В. І.) было больше, чем во всей Киевской губернии вместе с её духовною академиею и университетом» ${ }^{37}$.

У своїх численних розмовах вони пристрасно дискутували на історичні теми, але старанно обминали питання релігії ${ }^{38}$, хоча Куліша вони дуже цікавили. Особливості цих дискусій Куліш відобразив у другому томі Записок о Южной Руси - 3 приводу так званого «Універсалу гетьмана Остряниці» обидва вони написали свої дискусійні статті на тему О причинах взаимного ожесточения поляков и малороссиян в XVII веке (стаття Грабовського на сторінках 309-320, а Куліша - 321-328). Куліш

\footnotetext{
35 Р. Кирчів, Украйнська тема в народознавчій парадигмі Адама Фішера, [в:] той самий, Студї з украӥнсько-польського етнокультурного пограниччя, Львів 2013, с. 368.

36 За твердженням В.Я. Гнатюка, рукопис Pan starosta Zakrzewski (думаю, це були уривки) спершу було видрукувано 1843 р. в альманасі «Radegast» Адама Гонорія Кіркора (Wilno, 1843) - див.: В. Гнатюк, цит. праця, с. 101. 1845 р. з'явився передрук більшої частину цього тексту у виданні «Pamiętniki Umysłowe» (S. Kubasiński, Pan starosta Zakrzewski, Wilno 1845, t. 1, s. 1-184). Згодом вийшло друком ще одне видання твору див.: Pan starosta Zakrzewski. Wydat Michat Grabowski, Kijów 1860, s. VI, 157.

37 П. Кулиш, Хуторская философия..., с. 76-77.

38 Куліш зазначив таку цікаву деталь: «во время моего неоднократного пребывания у Грабовского, он до того свыкся со мною, что даже молился в моём присутствии по молитвеннику, который лежал у него на карнизе камина (Ołtarzyk złoty)» (П. Куліш, Около полустолетия назад..., с. 140).
} 
так прокоментував цю обставину своєї співпраці з Грабовським у листі до Михайла Юзефовича від 23 січня 1857 року:

«Бувши в Кийові, читали ми вкупі з паном Грабовським універсал гетьмана Остряниці й мізкували над ним - він польською і шляхетською, а я южноруською і козацькою головою. Послі ми списали своє мізковання на папір, і тепер його цензура після довгої волокити пропустила. [...] Тут не в універсалі штука, а в тому, що пишуть польський пан і український козак в дев'яmнадиятому віку про гетьманський універсал сімнадиятого віку. [...] Пан Грабовський мого писання не знає, а прочитавши (це нехай буде між нами), може, й він носом закрутить» ${ }^{39}$.

В Записках о Южной Руси неодноразово згадано й відомого польського історика та етнографа Едварда Руліковського, зокрема його працю Opis powiatu wasylkowskiego pod względem historycznym, obyczajowym i statystycznym (Warszawa, 1853), з якої наприкінці першого тому Записок о Южной Руси Куліш передрукував фрагмент «Уривок із пісні про розорення Києва Батиєм» (принагідно зазначу, що цю частину тексту Записок значною мірою обгрунтовано критикував Іван Франко у статті Ведмедів$\kappa a$, що входить до його об'ємної праці Студії над украйнськими народними піснями). Куліш використовував зазначену монографію Руліковського і для ілюстрації своїх роздумів про життя і діяльність Семена Палія, для коментаря щодо публікації $O$ причинах взаимного ожесточения поляков и малороссиян в XVII веке тощо.

Характеризуючи особу Семена Палія, Куліш через Руліковського покликався на працю польського історика Еразма II Франтішка Отвіновського (?-1745), ймовірного автора хроніки Pamiętniki do panowania Augusta II. Napisane przez niewiadomego autora (podobno Erazma Otwinowskiego). Wydane z rękopismu przez Edwarda Raczyńskiego. - Poznań, 1838 (iі друге видання вийшло під назвою Dzieje Polski pod panowaniem Augusta II od roku 1696 do 1728. - Kraków, 1849). Серед Кулішевих джерел праця польського письменника та історика, автора перших творів польською мовою Марціна Бєльського (1495-1575) Kronika Polska Marcina Bielskiego (1597), видана $з$ доповненням його сина Йоахіма, що містить важливі відомості про Україну, зокрема, про початки козаччини.

Хоча в Записках о Южной Руси Куліш не згадав про Еразма Ізопольського (1810-1876), про їхню фольклористичну працю уже йшлося в народознавчій науці. Досліджуючи україніку польського вченого і письменника Яна Мірослава Касіяна, Р. Кирчів проаналізував його працю про цікаву романтичну поему Е. Ізопольського Duma z dum ukraińskich:

39 Пантелеймон Куліш - Михайлу Юзефовичеві, Лист від 23 січня 1857 року, «Киевская старина» 1899, март, с. 316-317. 
на думку українського фольклориста, твір Ізопольського типологічний поемі-епопеї Куліша Украӥна, яка, як уже йшлося, укладена з народних дум та Кулішевих стилізацій ${ }^{40}$.

Варто бодай стисло сказати і про доброзичливе спілкування Куліша 3 відомим тогочасним польським меценатом і колекціонером Константієм Свідзінським (1793-1855), котрого український письменник називав «великим поборником польской национальности» ${ }^{41}$, яке поєднувалося 3 любов'ю до української культури: «что всего поразительнее было для меня, так это его любовь ко всему малороссийскому» ${ }^{42}$.

Знайомство Куліша й Свідзінського сталося завдяки Міхалу Грабовському 1843 року. Свідзінський володів унікальною колекцією рукописів, 3-поміж яких Куліша особливо зацікавив літопис Йоахіма Єрлича, а також стародруків. Український романтик писав, що Свідзінський мав значний вплив формування його як історика, прихильно ставився до української літератури, зокрема дав гроші на видання творів Шевченка, зберігав його гравюри. Свідзінський звернув увагу Куліша на польські історичні джерела, що зрештою суттєво вплинуло на концепцію його історіографічних студій 1870-1880-х років - йдеться про Историю воссоединения Руси та Отпадение Малороссии от Польши. Хоча, за словами Куліша, у 1840-1850-ті роки його із Свідзінським погляди «на русько-польську старовину були діаметрально протилежними, але оскільки кожен із нас щиро любив свою справу, то охоче вислуховував і суперечності» ${ }^{43}$.

Відомо, що Куліш подарував Свідзінському рукопис так званої Думи-сказання про морський похід старшого князя-язичника в християнську землю (див.: Записки о Южной Руси, т. 1, с. 172-178), яку начебто записав, а виглядає так, що написав відомий український поет-романтик Олександр Шишацький-Ілліч. Куліш читав цю «думу» Свідзінському за кілька днів до його смерти, бо той вважав цей твір «важливим відкриттям» в українській словесності. В другому томі Записок о Южной Руси (СПб., 1857) при публікації своєї відомої ідилії Орися Куліш зокрема написав: «Писано 1844, сентября 7, у Ходоркові, в Свідзінського, прочитавши шесту пісню Одиссеї»).

Зазначу, що характеризуючи гайдамацький рух в Україні 1760-х років, Куліш неодноразово покликався на польські джерела. Так, Куліш добре знав написані 1827 р. спогади про Коліївщину Вероніки (Констанції) Кребс (бл. 1750-1832), доньки уманського управителя Рафаїла Млада-

40 Р. Кирчів, Украӥніка Яна Мірослава Касіяна, [в:] той самий, Студї з украӥнсько-польського етнокультурного пограниччя, Львів 2013, с. 400-401.

41 П. Куліш, Воспоминание русского о польском археологе Константине Свидзинском, [в:] Хроніка 2000. Український культурологічний альманах, Київ 2009, Вип. 78, с. 183.

42 Там само, с. 186.

43 Там само, с. 183. 
новіча, якого 1768 р. вбили гайдамаки: Opis autentyczny rzezi Humańskiej przez córke gubernatora Humania, z Mładanowiczów zamężna Krebsowa. $Z$ manuskryptów Hr. T. Dziatyńskiego, przedrukowany $z$ orędownika naukowego (Poznań, 1840, 49 s.). Згодом їх було перекладено російською й опубліковано під назвою: Уманская резня / Записки Вероники Кребс (Перевод с предисловием И. М. Рева, Киев, 1879, 36 с.).

Те саме можна сказати і про мемуари Яна Ліппомана Bunt Hajdamaków na Ukrainie r. 1768. Opisany przez J. Lippomana i dwóch bezimiennych. Wydane z rękopismu przez Edwarda Raczyńskiego (Poznań, 1842, t. XV, 221 s.).

Як бачимо, польський контекст у фольклористичній чи, ширше, народознавчій діяльності Пантелеймона Куліша досить значний, що свідчить про актуальність спеціяльної розлогої праці на тему Творча сnадщина Пантелеймона Куліша і польська література, яка, сподіваюсь, знайде свого автора.

\section{БІБЛІОГРАФІЯ}

Âgič Ignatij [Vatroslav]. 1910. Istoriâ slavânskoj filologii. SPb.: Izdanie Imperatorskoj akademii nauk. [Ягич Игнатий [Ватрослав]. 1910. История славянской филологии. СПб.: Издание Императорской академии наук].

Gnatûk Volodimir. 1929. Pol's'kij literator M.A. Grabovs'kij ì jogo priâtelûvannâ z P. O. Kulišem. „Zapiski ìstorično-fîlologì̌nogo Vìddilu Vseukraïns'koï Akademiï nauk". Kiïv: drukarnì Vseukraïns'koï Akademiï Nauk, kn. XXIII: 97-124. [Гнатюк Володимир. 1929. Польський літератор М.А. Грабовський і його приятелювання з П.О. Кулішем. ,Записки історично-філологічного Відділу Всеукраїнської Академії Наук”. Київ: 3 друкарні Всеукраїнської Академії Наук, кн. XXIII: 97-124].

Ìvaškìv Vasil'. 2019. Fol'klor u naukovomu ta pis'mennic'komu diskursi Pantelejmona Kuliša (1840-1850-tì roki). ,Bûleten' Naukovogo Tovaristva ìm. Ševčenka v Americi”. Čislo 48 (64). N'û-Jork: 10-15. [Івашків Василь. 2019. Фольклор у науковому та письменницькому дискурсі Пантелеймона Куліша (1840-1850-ті роки). „Бюлетень Наукового Товариства ім. Шевченка в Америці”. Число 48 (64). Нью-Йорк: $10-15]$.

Kirčiv Roman. 2013. Perekladi ukraïns'kih pìsen' pol's'koû movoû. V: Kirčìv Roman. Studï z ukraïns'ko-pol's'kogo etnokul'turnogo pograniččâ. L'vìv: LNU ìmenì İvana Franka: 256-273. [Кирчів Роман. 2013. Переклади українських пісень польською мовою. В: Кирчів Роман. Студї з украӥнсько-польського етнокультурного пограниччя. Львів: ЛНУ імені Івана Франка: 256-273].

Kirčiv Roman. 2013. Ukraïns'ka tema v narodoznavčì paradigmi Adama Fišera. V: Kirčìv Roman. 2013. Studï̈ z ukraïns'ko-pol's'kogo etnokul'turnogo pograniččâ. L'vìv: LNU ìmenì Ìvana Franka: 363-391. [Кирчів Роман. 2013. Українська тема в народознавчій парадигмі Адама Фішера В: Кирчів Роман. Студії з украӥнсько-польського етнокультурного пограниччя. Львів: ЛНУ імені Івана Франка: 363-391].

Kirčìv Roman. 2013. Ukraïnika Âna Miroslava Kasiâna. V: Kirčiv Roman. Studï z ukraïns'ko-pol's'kogo etnokul'turnogo pograniččâ. L'vìv: LNU ìmenì Ìvana Franka: 392-407. [Кирчів Роман. 2013. Украӥніка Яна Мірослава Касіяна. В: Кирчів Ро- 
ман. Студї з украӥнсько-польського етнокультурного пограниччя. Львів: ЛНУ імені Івана Франка: 392-407].

Kubasiński Sylenty. 1845. Pan starosta Zakrzewski. Wilno: Nakład i druk T. Glücksberga, t. 1. Kuliš Pantelejmon. 1882. Krašanka rusinam ì polâkam na Velikden' 1882 roku. L'vìv: z Drukarnì Tovaristva ìmeni Ševčenka. [Куліш Пантелеймон. 1882. Крашанка русинам і полякам на Великдень 1882 року. Львів: з Друкарні Товариства імени Шевченка].

Kuliš Pantelejmon. 2000. Okolo polustoletiâ nazad. Literaturnye vospominaniâ. V: Pantelejmon Kuliš. Materìali i doslìzžennâ. L'vìv-N'û-Jork: Vidavnictvo M.P. Кос':110-156. [Куліш Пантелеймон. 2000. Около полустолетия назад. Литературные воспоминания. В: Пантелеймон Куліш. Матеріали і дослідження. Львів-Нью-Йорк: Видавництво М.П. Коць:110-156].

Kuliš Pantelejmon. 2009. Vospominanie russkogo o pol'skom arheologe Konstantine Svidzinskom. Pantelejmon Kulǐs: pis'mennik, filosof, gromadânin. Do 190-rìččâ vìd dnâ narodžennâ P.O. Kuliša / Hronìka 2000. Ukraïns'kij kul'turologičnij al'manah. Kiïv, vipusk 78: 183-187. [Куліш Пантелеймон. 2009. Воспоминание русского о польском археологе Константине Свидзинском. Пантелеймон Куліш: письменник, філософ, громадянин. До 190-річчя від дня народження П.О. Куліша / Хроніка 2000. Український культурологічний альманах. Київ, випуск 78: 183-187].

Kuliš Pantelejmon. 1879. Hutorskaâ filosofiâ i udalennaâ ot sveta poèziâ. Sankt-Peterburg: Tipografiâ Tovariŝestva «Obŝestvennaâ pol'za». [Кулиш Пантелеймон. 1879. Хyторская философия и удаленная от света поэзия. Санкт-Петербург: Типография Товарищества «Общественная польза»].

Kuliš Pantelejmon. 2005. Povne zibrannâ tvorìv. Listi. Kiïv: Kritika, t. 1: 1841-1850, uporâd., koment. O. Fedoruk. [Куліш Пантелеймон. 2005. Повне зібрання творів. Листи. Київ: Критика, т. 1: 1841-1850, упоряд., комент. О. Федорук].

Kuliš Pantelejmon. 2015. Povne zibrannâ tvorì. Naukovi pracì. Publicistika. Kï̈v: Kritika, t. 3, Zapiski o Užnoj Rusi, u 2 kn., kn. 1, uporâd., pìdgot. tekstìv, stattâ, koment. V. İvaškìv. [Куліш Пантелеймон. 2015. Повне зібрання творів. Наукові праці. Публіцистика. Київ: Критика, т. 3, Записки о Южной Руси, у 2 кн., кн. 1, упоряд., підгот. текстів, стаття, комент. В. Івашків].

Nahlik Êvgen. 2007. Pantelejmon Kulǐš: Osobistìst', pis'mennik,mislitel': Naukova monografiâ u 2-h tomah. Kiïv: Ukraïns'kij pis'mennik, t. 2: Svitoglâd i tvorčìst' Pantelejmona Kuliša. [Нахлік Свген. 2007. Пантелеймон Куліш: Особистість, письменник, мислитель: Наукова монографія у 2-х томах. Київ: Український письменник, т. 2: Світогляд і творчість Пантелеймона Куліша].

Pan starosta Zakrzewski. Wydat Michat Grabowski. 1860. Kijów, nakł. Leona Idzikowskiego, druk. Gazety Codziennej w Warszawie.

Pypin Aleksandr. 1891. Istoriâ russkoj ètnografii. SPb.: Tip. M. M. Stasûleviča, t. 3. Ètnografiâ malorusskâ̂. [Пыпин Александр. 1891. История русской этнографии. СПб.: Тип. М. М. Стасюлевича, т. 3. Этнография малорусская].

Ûrovs'ka Olena. 1929. Kuliš i Grabovs'kij. Ukraïna, kniga 36: 72-85. [Юровська Олена. 1929. Куліш і Грабовський. Україна, книга 36:72-85].

Fischer Adam. 1928. Rusini. Zarys etnografji Rusi. Z tablicami i 33 ilustracjami. LwówWarszawa-Kraków: Zakład Narodowy im. Ossolińskich.

Sow[iński] Leonard. 1875. Duma o Marysi Bogusławiance (z małoruskiego). «Kłosy». № 509: 195-198. 


\section{PANTELEYMON KULISH'S FOLKLORISTIC ACTIVITY IN THE POLISH CONTEXT}

Summary. The given article outlines the Polish context of Panteleymon Kulish's folkloristic activity in the1840-1850-ies, which involved the Ukrainian writer and folklorist's cooperation with Polish artists and culture activists, namely Michał Grabowski, Konstantij Świdziński and Edward Rulikowski, who lived in Ukraine at that time. This partnership resulted in publication of translations of numerous legends and stories from Kulish's manuscript collection as well as analysis of Kulish's work as a folklorist in a comprehensive article by Grabowski $O$ gminnych ukrainskich podaniach in the journal «Rubon» (1845). The given paper underlines Grabowski's role in forming the contents and the concept of Kulish's unique work Записки о Южной Руси (Notes on the Southern Rus) (1856, vol. 1; 1857, vol. 2), which has no analogues in folklore studies and ethnology of those times.

Key words: Ukrainian folklore, Polish-Ukrainian cooperation, Panteleymon Kulish, Michal Grabowski

\section{DZIAŁALNOŚĆ FOLKLORYSTYCZNA PANTELEJMONA KULISZA: KONTEKST POLSKI}

Streszczenie: W artykule scharakteryzowano kontekst polski działalności folklorystycznej Pantelejmona Kulisza z lat 1840-1850; kontekst ten obejmuje współpracę folklorysty i pisarza ukraińskiego z polskimi twórcami i działaczami kultury, w szczególności z Michałem Grabowskim, a także z Konstantym Świdzińskim i Edwardem Rulikowskim, zamieszkałymi wówczas na Ukrainie. Efektem współpracy stała się publikacja licznych przekładów tekstów legend i przekazów pochodzących z rękopiśmiennego zbioru Kulisza, a także analiza pracy Kulisza jako folklorysty, opublikowana w obszernym artykule Grabowskiego O gminnych ukraińskich podaniach w czasopiśmie „Rubon” (1845). Podkreślono wpływ Grabowskiego na dobór treści i kształtowanie koncepcji unikatowej pracy Kulisza pt. Записки о Южной Руси, która w ówczesnej folklorystyce i etnologii nie posiadała odpowiedników.

Słowa klucze: folklor ukraiński, współpraca polsko-ukraińska, Pantelejmon Kulisz, Michał Grabowski 
